\title{
Production of soluble eukaryotic recombinant proteins in E. coli is favoured in early log-phase cultures induced at low temperature
}

\author{
Teresa San-Miguel, Pedro Pérez-Bermúdez and Isabel Gavidia*
}

\begin{abstract}
Background: Producing recombinant plant proteins expressed in Escherichia coli produce in high yields and in a soluble and functional form can be difficult. Under overexpression conditions, proteins frequently accumulate as insoluble aggregates (inclusion bodies) within the producing bacteria. We evaluated how the initial culture density, temperature and duration of the expression stage affect the production of some eukaryotic enzymes in E. coli.

Findings: A high yield of active soluble proteins was obtained by combining early-log phase cultures and low temperatures for protein induction. When IPTG was added at $\mathrm{OD}_{600}=0.1$ and cultures were maintained at $4^{\circ} \mathrm{C}$ for 48-72 $\mathrm{h}$, the soluble protein yield was 3 fold higher than that obtained in the mid-log phase $\left(\mathrm{OD}_{600}=0.6\right)$. Besides, the target protein expression increased and the endogenous bacterial proteins reduced, thus making the protein purification process easier and more efficient.

Conclusions: The protocol can be widely applied to proteins with a heterologous expression which was limited by loss of activity at high temperatures or by low soluble recombinant protein yield.
\end{abstract}

Keywords: Early log phase, Functional proteins, Low temperature, Soluble recombinant proteins

\section{Findings}

\section{Background}

One important limitation for the production of recombinant proteins in Escherichia coli is obtaining large amounts of soluble and functional proteins. Under overexpression conditions, proteins frequently accumulate as insoluble aggregates (inclusion bodies) within producing bacteria. The production of soluble proteins under native conditions is essential for functional and structural analyses. Therefore, many studies have focused on optimising processes in protein expression (see Peti and Page 2007). One possibility is the solubilisation of proteins from inclusion bodies, but it usually requires denaturing conditions, and the subsequent renaturing step can prove difficult. Several experimental approaches have been developed to prevent these aggregates from forming, which include the use of cold inducible expression systems (Qing et al. 2004, Thuy Le and Schumann
2007), to increase the intracellular concentration of molecular chaperones (Mogk et al. 2002), to reduce the IPTG concentration for induction (Winograd et al. 1993), to induce the expression in a late log phase culture (Galloway et al. 2003), and to lower the growth temperature of induced cultures (Schein and Noteborn 1988, Vera et al. 2007).

In previous works, we reported the isolation and biochemical characterisation of genes $P 5 \beta R$ (Gavidia et al. 2007) and P5 $\beta R 2$ (Pérez-Bermúdez et al. 2010), which encode progesterone $5 \beta$-reductase (P5 $\beta \mathrm{R})$. These enzymes catalyse the $5 \beta$-reduction of progesterone to $5 \beta$ pregnan-3,20-dione as the first committed step in the biosynthetic pathway leading to cardiac glycosides in Digitalis species. In order to increase active enzyme yield, this study evaluated the effects of different temperatures and induction periods, and of varied initial culture densities, on the recombinant P5 $\beta$ R2 expression levels.

\footnotetext{
* Correspondence: isabel.gavidia@uv.es

Departamento de Biología Vegetal, Facultad de Farmacia, Universidad de Valencia, Av. VA Estellés s/n, Burjasot 46100, Spain
} 


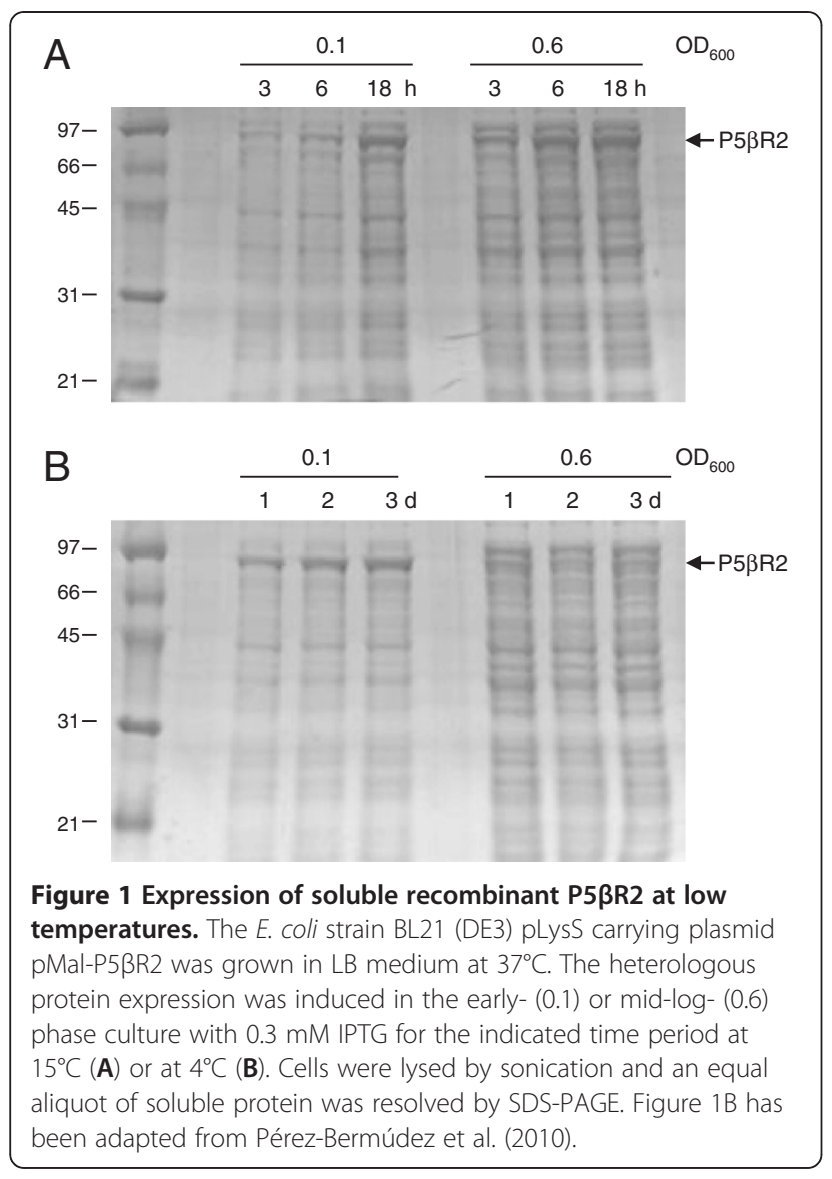

\section{Methods}

The full-length open-reading frame of $P 5 \beta R 2 \mathrm{cDNA}$ was amplified by PCR to include the PstI restriction site at the $3^{\prime}$ end by using Pfu DNA polymerase. The product was subcloned into the XmnI-PstI sites of the pMAL-c2 vector (New England Biolabs) and was expressed as a fusion protein with the maltose-binding-protein (MBP) at the $\mathrm{N}$ terminus. The constructed vector was transformed into E. coli BL21(DE3)pLysS. An overnight $3 \mathrm{ml}$ culture from a single colony was grown at $37^{\circ} \mathrm{C}$ in $\mathrm{LB}$ medium containing $100 \mathrm{mg} / \mathrm{l}$ of ampicillin, and was then transferred to $25 \mathrm{ml}$ LB supplemented with glucose $(2 \mathrm{~g} / \mathrm{l})$ and ampicillin. After incubation at $37^{\circ} \mathrm{C}$, the culture volume was increased to $150 \mathrm{ml}$. Gene expression was induced by the addition of $0.3 \mathrm{mM}$ IPTG to the cultures with different cell densities. Expression cultures were grown in Erlenmeyer flasks $(250 \mathrm{ml}$ ) with vented caps (PTFE membrane, $0.22 \mu \mathrm{m}$ pore size). Protein production was evaluated in cultures which were induced when $\mathrm{OD}_{600}$ was 0.1 (early log phase), 0.6 (mid log phase) and 1 (late log phase). Cultures were placed at $37,25,15$ or $4^{\circ} \mathrm{C}$ and were shaken at $200 \mathrm{rpm}$ for different incubation periods $(2-72 \mathrm{~h})$. Before the protein expression induction, cultures were cooled until they reached their respective growth temperatures.

After induction, cells were harvested by centrifugation at $4,000 \mathrm{rpm}$ for $20 \mathrm{~min}$ at $4{ }^{\circ} \mathrm{C}$ and were frozen at $-20^{\circ} \mathrm{C}$. Cells were disrupted by sonication in buffer A $(20 \mathrm{mM}$ Tris-HCl pH 7.4, $200 \mathrm{mM} \mathrm{NaCl}, 1 \mathrm{mM}$ EDTA, $1 \mathrm{mM}$ DTT and $0.2 \mathrm{mM}$ PMSF), and soluble protein extracts were obtained after centrifugation at 12,000 $\mathrm{g}$ for $10 \mathrm{~min}$. The MBP-tagged P5 $\beta R 2$ protein was then purified to apparent homogeneity in buffer B (buffer A with $10 \mathrm{mM}$ maltose) by amylose resin column chromatography (New England Biolabs), following the supplier's protocol. The electrophoretic separation of proteins was performed on $12 \%$ polyacrylamide gels according to Laemmli (1970). Proteins were quantified by the method described by Bradford (1976). Experiments were performed in triplicate. The study was approved by the institutional Ethics Commision in Experimental Research of the University of Valencia (Spain).

\section{Results and discussion}

Progesterone $5 \beta$-reductase belongs to the short-chain dehydrogenase/reductase (SDR) superfamily, and has been considered a key enzyme in cardenolide biosynthesis since it is the first stereospecific enzyme of the pathway leading to 5 $\beta$-configured intermediates (Roca-Pérez et al. 2004, Gavidia et al. 2007, Pérez-Bermúdez et al. 2010).

Our results demonstrated that obtaining this steroid reductase in a functional form absolutely depends on the temperature at which induction is performed. The induced cultures grown at $37^{\circ} \mathrm{C}$ (for $2 \mathrm{~h}$ or $3 \mathrm{~h}$ ) or at $25^{\circ} \mathrm{C}$ (for $4 \mathrm{~h}$ or $6 \mathrm{~h}$ ) did not produce active protein at any density. Thus only the induced cultures grown at $15^{\circ} \mathrm{C}$, or at lower temperatures, produced the active MBP-P5 $\beta$ R2 fusion protein (for details about enzyme activity, see Pérez-Bermúdez et al. 2010). Moreover, using the cultures of $\mathrm{OD}_{600}=1$ for protein induction did not improve the results obtained with the cultures of $\mathrm{OD}_{600}=0.6$ irrespectively of whether the expression was carried out at $15^{\circ} \mathrm{C}$ or $4{ }^{\circ} \mathrm{C}$, the yields of soluble protein obtained in both trials were almost identical.

Within the $15^{\circ} \mathrm{C}$ and $4^{\circ} \mathrm{C}$ temperature range, the highest soluble protein yield was obtained at $18 \mathrm{~h}$ and $72 \mathrm{~h}$,

Table 1 Quantitative overview of recombinant P5 $\beta$ R2 purification in the early- $(0.1)$ or mid-log- (0.6) phase culture

\begin{tabular}{|c|c|c|c|c|c|c|}
\hline \multirow{2}{*}{$\begin{array}{l}\text { Culture } \\
\text { density }\end{array}$} & \multicolumn{3}{|c|}{$4^{\circ} \mathrm{C} / 72 \mathrm{~h}$} & \multicolumn{3}{|c|}{$15^{\circ} \mathrm{C} / 18 \mathrm{~h}$} \\
\hline & P5 $\beta R 2$ (mg) & Total protein in cell lysate $(\mathrm{mg})$ & Yield (\%) & P5ßR2 (mg) & Total protein in cell lysate $(\mathrm{mg})$ & Yield (\%) \\
\hline $\mathrm{OD}_{600}=0.1$ & $3.6 \pm 0.2$ & $12.1 \pm 1.3$ & 30 & $3.5 \pm 0.3$ & $21.4 \pm 1.9$ & 16 \\
\hline $\mathrm{OD}_{600}=0.6$ & $1.4 \pm 0.2$ & $20.8 \pm 3.4$ & 8 & $3.8 \pm 0.4$ & $23.0 \pm 2.8$ & 17 \\
\hline
\end{tabular}

Escherichia coli cultures were incubated at low temperatures $\left(4^{\circ} \mathrm{C}\right.$ or $\left.15^{\circ} \mathrm{C}\right)$ for the indicated time period. Data are the mean values $( \pm \mathrm{SD})$ from three separate $150 \mathrm{ml}$ expression cultures. 
respectively. When protein induction was carried out at $15^{\circ} \mathrm{C}$, the production rate was similar at both cell densities, the early or mid log phase, after $18 \mathrm{~h}$ of incubation (Figure 1A). At this temperature, the cultures induced at the early-log phase presented a slightly low endogenous protein production (Table 1). However, when the protein expression commenced in the bacteria grown at $4^{\circ} \mathrm{C}$, the most significant soluble P5 $\beta$ R2 production was obtained in those cultures induced in the early log phase. Thus, when IPTG was added at $\mathrm{OD}_{600}=0.1$ and cultures were maintained at $4^{\circ} \mathrm{C}$ for $48-72 \mathrm{~h}$, the amount of soluble protein was 2-3-fold higher (Table 1) than that obtained when IPTG was added in the mid-log phase $\left(\mathrm{OD}_{600}=0.6\right)$ (Figures $1 \mathrm{~B}$ and 2). Under these conditions, the purified P5 $\beta R 2$ recovered from $150 \mathrm{ml}$ of culture was $3-4 \mathrm{mg}$, and the expression of the endogenous bacterial proteins lowered 30\% (Table 1). Thus, the protein purification process proved more amenable and efficient. P5 $\beta$ R2 synthesis was maintained for $72 \mathrm{~h}$ after induction (Figure 1B), indicating that cells under those conditions retained the protein-synthesising capacity for more than 3 days.

It is known that the overexpression of the proteins in E. coli at low temperatures usually improves both protein solubility and activity (see Sahdev et al. 2008). Accordingly, it has been reported that preferred induction temperatures would fall in the $16^{\circ} \mathrm{C}-23^{\circ} \mathrm{C}$ range (Niiranen et al. 2007, Vera et al. 2007, Peti and Page 2007), but also at around $10^{\circ} \mathrm{C}$ (Vasina and Baneyx 1997, Pacheco et al. 2012). Yet, as far as we know, protein expression in early log phase cultures $\left(\mathrm{OD}_{600}=0.1\right)$ has not been reported. Low growth rates are usually associated with a low protein synthesis rate, which is consistent with our observations for the production of endogenous bacterial proteins, but not with recombinant protein yield. It is noteworthy that, the data presented herein demonstrate that the high soluble protein yield from the early log-phase cultures, grown at temperatures as low as $4^{\circ} \mathrm{C}$, does not correlate with a high cell

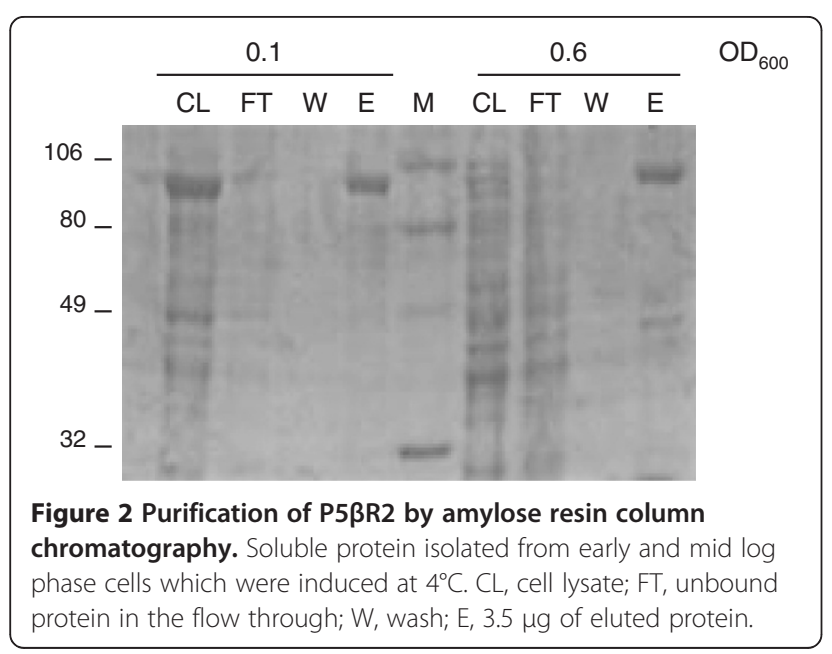

number (Table 1). Although $4^{\circ} \mathrm{C}$ is a low temperature, the bacterium grows. Actually, an E. coli culture induced to generate the recombinant $\mathrm{P} 5 \beta \mathrm{R} 2$ protein $\left(\mathrm{OD}_{600}=0.1\right)$ produced a biomass of ca. $45-50 \mathrm{mg}$ fresh wt/150 ml cultivation broth in $72 \mathrm{~h}$ at $4^{\circ} \mathrm{C}$. This growth cannot be associated with the recombinant P5 3 R2 expression since E. coli cultures showed a similar growth rate when bacteria were transformed with the empty vector. In line with this, there have been reports that the expression of some heterologous proteins (chaperonins) determine E. coli growth at low temperatures; thus, transgenic strains grew at temperatures below $4^{\circ} \mathrm{C}$ and the theoretically minimum temperature for growth would be as low as $-13.7^{\circ} \mathrm{C}$ (Ferrer et al. 2003).

We also observed that slow-growing cultures were more permissive for expressing heterologous proteins than rapid-growing ones in which protein translation is maximal. In our trials, this behaviour was not exclusive of the pMAL system and the BL21(DE3)pLysS strain, since we obtained similar production rates using the $\mathrm{pQE}$ (Qiagen) and $\mathrm{pET}$ (Novagen) systems with different $E$. coli strains, such as M15[pREP4], SG13009[pREP4] and BL21(DE3).

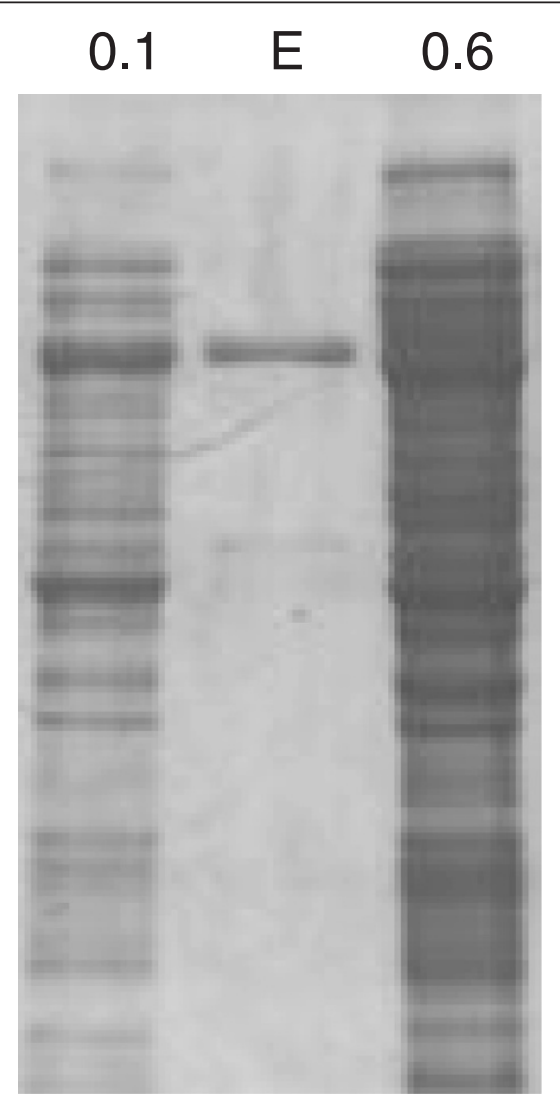

Figure 3 Expression of Echinostoma caproni HSP70 using the pQE30 expression vector and E. coli M15[pREP4] strain. The heterologous protein expression was induced in the early- (0.1) or mid-log- (0.6) phase culture with $0.3 \mathrm{mM} \mathrm{IPTG}$ at $4^{\circ} \mathrm{C}$. Cells were lysed by sonication and an equal aliquot of soluble protein was resolved by SDS-PAGE. E, $3.5 \mu \mathrm{g}$ of eluted protein. 
Finally, our protocols have also been incorporated into protocols for the expression of proteins from other organisms, such as HSP70 from the parasite Echinostoma caproni. E. caproni HSP70 is in part soluble and another part is insoluble. Furthermore, its expression in E. coli required the use of $8 \mathrm{M}$ urea to improve the solubility of the heterologous protein (Higón et al. 2008). In the present trial, the heterologous expression of E. caproni HSP70 was induced in early- $(0.1)$ or mid-log-phase (0.6) cultures at $4^{\circ} \mathrm{C}$. The obtained results demonstrate the successful application of the protocol and that protein expression is favoured in early log-phase cultures induced at low temperatures (Figure 3) as compared with typically recommended culture conditions $\left(\mathrm{OD}_{600}=0.6\right)$. Therefore, this protocol may be widely applied to proteins with a heterologous expression which is limited by loss of activity at high temperatures or by low soluble recombinant protein yield.

\section{Competing interests}

The authors declare that they have no competing interests.

\section{Authors' contributions}

IG conceived and designed the study. TSM carried out most of the experimental work. IG and PPB analysed the data and drafted the manuscript. All the authors read and approved the final manuscript.

\section{Acknowledgements}

This work has been supported by the Universidad de Valencia (AE-20070215) and the Ministerio de Ciencia e Innovación (BFU2008-01420/BMC). IG has received financial support from a Ramón y Cajal contract from the Spanish Ministerio de Educación y Ciencia. Dr. Antonio Marcilla (Dept. of Parasitology, Universidad de Valencia) provided the EcHSP70 construction. The authors thank four anonymous reviewers for their helpful comments on an earlier version of this article. We appreciate the technical assistance provided by the SCSIE of the University of Valencia.

Received: 20 December 2012 Accepted: 4 March 2013

Published: 8 March 2013

\section{References}

Bradford MM (1976) A rapid and sensitive method for the quantitation of microgram quantities of protein utilizing the principle of protein-dye binding. Anal Biochem 72:248-254

Ferrer M, Chernikova TN, Yakimov MM, Golyshin PN, Timmis KN (2003) Chaperons govern growth of Escherichia coli at low temperature. Nat Biotechnol 21:1266-1267

Galloway CA, Sowden MP, Smith HC (2003) Generations of chromosome paints: approach for increasing specifity and intensity of signals. Biotechniques 34:530-536

Gavidia I, Tarrío R, Rodríguez-Trelles F, Pérez-Bermúdez P, Seitz HU (2007) Plant progesterone $5 \beta$-reductase is not homologous to the animal enzyme. Molecular evolutionary characterization of P5 $3 \mathrm{R}$ from Digitalis purpurea. Phytochemistry 68:853-864

Higón M, Monteagudo C, Fried B, Esteban JG, Toledo R, Marcilla A (2008) Molecular cloning and characterization of Echinostoma caproni heat shock protein-70 and differential expression in the parasite derived from low- and high-compatible hosts. Parasitology 135:1469-1477

Laemmli UK (1970) Cleavage of structural proteins during the assembly of the head of bacteriophage T4. Nature 227:680-685

Mogk A, Mayer MP, Deuerling E (2002) Mechanisms of protein folding: molecular chaperones and their application in biotechnology. Chem-biochem 3:807-814

Niiranen L, Espelid S, Karlsen CR, Mustonen M, Paulsen SM, Heikinheimo P, Willassen NP (2007) Comparative expression study to increase the solubility of cold adapted Vibrio proteins in Escherichia coli. Protein Expr Purif $52: 210-218$
Pacheco B, Crombet L, Loppnau P, Cossar D (2012) A screening strategy for heterologous protein expression in Escherichia coli with the highest return of investment. Protein Expr Purif 81:33-41

Pérez-Bermúdez P, Moya García AA, Tuñon I, Gavidia I (2010) Digitalis purpurea $P 5 \beta R 2$, encoding steroid $5 \beta$-reductase, is a novel defense-related gene involved in cardenolide biosynthesis. New Phytol 185:687-700

Peti W, Page R (2007) Strategies to maximize heterologous protein expression in Escherichia coli with minimal cost. Protein Expr Purif 51:1-10

Qing G, Ma L-C, Khorchid A, Swapna GVT, Mal TK, Takayama MM, Xia B, Phadtare $\mathrm{S}$, Ke H, Acton T, Montelione GT, Ikura M, Inouye M (2004) Cold-shock induced high-yield protein production in Escherichia coli. Nat Biotechnol 22:877-882

Roca-Pérez L, Boluda R, Gavidia I, Pérez-Bermúdez P (2004) Seasonal cardenolide production and Dop $5 \beta$ r gene expression in natural populations of Digitalis obscura. Phytochemistry 65:1869-1878

Sahdev S, Khattar SK, Saini KS (2008) Production of active eukaryotic proteins through bacterial expression systems: a review of the existing biotechnology strategies. Mol Cell Biochem 307:249-264

Schein CH, Noteborn MHM (1988) Formation of soluble recombinant proteins in Escherichia coli is favored by lower growth temperature. Biotechnology 6:291-294

Le Thuy AT, Schumann W (2007) A novel cold-inducible expression system for Bacillus subtilis.-. Protein Expr Purif 53:264-269

Vasina JA, Baneyx F (1997) Expression of aggregation-prone recombinant proteins at low temperatures: A comparative study of the Escherichia coli cspA and tac promoter systems. Protein Expr Purif 9:211-218

Vera A, González-Montalbán N, Arís A, Villaverde A (2007) The conformational quality of insoluble recombinant proteins is enhanced at low growth temperatures. Biotechnol Bioeng 96:1101-1106

Winograd E, Pulido MA, Wasserman M (1993) Production of DNA-recombinant polypeptides by Tac-inducible vectors using micromolar concentrations of IPTG. Biotechniques 14:886-887

doi:10.1186/2193-1801-2-89

Cite this article as: San-Miguel et al:: Production of soluble eukaryotic recombinant proteins in $E$. coli is favoured in early log-phase cultures induced at low temperature. SpringerPlus 2013 2:89.

\section{Submit your manuscript to a SpringerOpen ${ }^{\odot}$ journal and benefit from:}

- Convenient online submission

- Rigorous peer review

- Immediate publication on acceptance

- Open access: articles freely available online

- High visibility within the field

- Retaining the copyright to your article

Submit your next manuscript at $>$ springeropen.com 